\title{
Investigation and environmental analysis of samples from outbreak of toxoplasmosis at research institution in Londrina, Paraná, Brazil, 2016
} Investigação e análise ambiental de amostras oriundas de surto de toxoplasmose em uma instituição de
pesquisa em Londrina, Paraná, Brasil, 2016

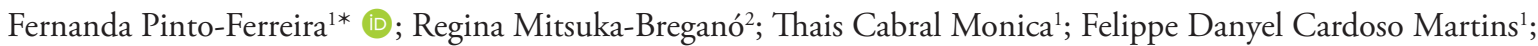
Ricardo Luís Nascimento de Matos ${ }^{1}$; Marcelle Mareze'; Beatriz de Souza Lima Nino ${ }^{1}$; Simone Garani Narciso;

Roberta Lemos Freire ${ }^{1}$; Italmar Teodorico Navarro ${ }^{1}$

\begin{abstract}
${ }^{1}$ Departamento de Medicina Veterinária Preventiva, Laboratório de Zoonoses e Saúde Pública, Universidade Estadual de Londrina UEL, Londrina, PR, Brasil

${ }^{2}$ Departamento de Medicina Veterinária Preventiva, Laboratório de Parasitologia Veterinária, Universidade Estadual de Londrina UEL, Londrina, PR, Brasil

${ }^{3}$ Secretaria de Saúde Municipal de Londrina, Londrina, PR, Brasil
\end{abstract}

Received January 14, 2019

Accepted May 22, 2019

\begin{abstract}
The objective of this study was to report an outbreak of human toxoplasmosis at a research institution in Londrina, Paraná, from December 2015 to February 2016. Blood samples from 26 symptomatic individuals were collected and the microparticle chemiluminescence immunoassay was performed to detect $\operatorname{IgM}, \operatorname{IgG}$ and specific $\operatorname{IgG}$ avidity test in the official laboratory. A total of 20 people with symptoms and serology compatible with acute toxoplasmosis (IgM positive and IgG with low avidity) were selected as cases, while 45 asymptomatic employees working in the same teams and during the same shifts were selected as controls. All the participants of the investigation answered an epidemiological questionnaire. Three samples of water and one sludge from the institution's supply cisterns, 10 soil samples, 11 plant samples, three cat fecal samples and one domestic feline cadaver were collected for analysis of the polymerase chain reaction (PCR) for T. gondii. After analyzing the epidemiological data, the consumption of vegetables in the restaurant of the institution was the only variable associated with the occurrence of the disease. In laboratory results, all the samples showed negative results to PCR. The rapid recognition of the outbreak, early notification and investigation could have broken the chain of transmission early, thus preventing the emergence of new cases. In addition, the adoption of good food handling practices could have prevented the occurrence of the outbreak.
\end{abstract}

Keywords: Epidemiology, Toxoplasma gondii, vegetables, foodborne, outbreak.

\section{Resumo}

O objetivo deste estudo foi relatar um surto de toxoplasmose humana em uma instituição de pesquisa em Londrina, Paraná, no período de dezembro de 2015 a fevereiro de 2016. Amostras de sangue de 26 indivíduos sintomáticos foram coletadas e o imunoensaio de quimioluminescência de micropartículas foi realizado para detectar $\operatorname{IgM}$, IgG e teste de avidez de IgG específica em laboratório oficial. Um total de 20 pessoas com sintomas e sorologia compatíveis com toxoplasmose aguda (IgM positiva e IgG com baixa avidez) foi selecionado como casos, enquanto 45 funcionários assintomáticos que trabalhavam nas mesmas equipes e durante os mesmos turnos foram utilizados como controles. Todos os participantes da investigação responderam a um questionário epidemiológico. Foram coletadas três amostras de água e uma de lodo das cisternas de abastecimento da instituição, 10 de solo, 11 de vegetais, três amostras de fezes de gato e um cadáver de filhote felino doméstico para detecção de T. gondii pela reação em cadeia da polimerase (PCR). Após análise dos dados epidemiológicos, o consumo de hortaliças no restaurante da instituição foi a única variável associada à

*Corresponding author: Fernanda Pinto-Ferreira. Departamento de

Medicina Veterinária Preventiva, Universidade Estadual de Londrina - UEL,

Avenida Juvenal Pietraroia, 1125, CEP 86057-080, Londrina, PR, Brasil.

e-mail: nandaferreiravet@gmail.com 
ocorrência da doença. Em resultados laboratoriais, todas as amostras apresentaram resultados negativos a PCR. O rápido reconhecimento do surto, notificação e investigação prematura poderia ter quebrado a cadeia de transmissão, evitando assim o surgimento de novos casos. Além disso, a adoção de boas práticas de manipulação de alimentos poderia ter impedido a ocorrência do surto.

Palavras-chave: Epidemiologia, Toxoplasma gondii, vegetais, origem alimentar, surto.

Toxoplasmosis is a zoonosis caused by the protozoan Toxoplasma gondii; due to its public' health importance, it is one of the most studied parasites in the world and can infect all homeothermic animals with felines serving as the definitive hosts (JACOBS \& MELTON, 1957). The transmission pathway of the agent is variable; however, eating habits as well as cultural and environmental factors are determinants of the epidemiology of toxoplasmosis (KOLBEKOVA et al., 2007).

In Brazil, outbreak notification and epidemiological research is a mandatory activity in health surveillance (BRASIL, 2017). Over the past 50 years, more than 40 outbreak reports for toxoplasmosis have been published worldwide, with the majority being in Brazil. The main transmission routes involved were water (MOURA et al., 2006), vegetables (EKMAN et al., 2012), fruits, undercooked meats or raw (POMARES et al., 2011) and unpasteurized goat's milk (CHIARI \& NEVES., 1984). The objective of this work was to describe an outbreak of toxoplasmosis that occurred at research institution located in the Municipality of Londrina, Paraná, Brazil.

On February 18, 2016, the Londrina Epidemiological Surveillance Coordination was informed of that three individuals had confirmed acute toxoplasmosis and five were presenting with clinical manifestations. All cases were reported from a research institution in the city of Londrina. Based on the reports, the hypothesis that there was an outbreak was proposed. Thus, an active search for acute toxoplasmosis cases was started, and all individuals who had been present at the institution's facilities from December 2015 to February 2016 were considered as potential cases, including those who had visited restaurants, consumed water collected by the company and had presented with at least one of the symptoms such as fever, myalgia, asthenia, headache, and lymphadenopathy.

A confirmed case was defined as individual who, in Microparticle Chemiluminescent Immunoassay (CMIA) (PETERSEN et al., 2005), presented antibodies of the IgM class reagent and IgG with low avidity. The individual that showed reagent IgM and IgG high-avidity or nonreactive IgM and reactive IgG were considered immune or with old exposure to the agent. These immune individuals, along with susceptible (nonreactive IgM and $\mathrm{IgG}$ ) individuals were not considered as part of the outbreak.

During the visit to the institution, information was collected about the daily menu provided by the restaurant during the study period, including information about the types of raw and cooked foods served. A semistructured questionnaire was applied to all participants, and information about gender, age, work area, eating habits, water consumption and soil manipulation was collected.

A case-control epidemiological study was carried out to identify the probable source of the contamination of the studied population using the information collected in the questionnaire and the results of the tests. For the analysis of the variables studied and comparisons of proportions, the chi-square test or Fisher's
Exact, with a significance level of 5\% and confidence interval of 95\% was used by software EpiInfo 3.5.4 (CDC, Atlanta, USA).

Three water samples (20 L of water from cisterns 1 and 2 and $10 \mathrm{~L}$ from cistern 3) were collected as well as a $500 \mathrm{~mL}$ sample from the sludge (cistern 1). Ten soil samples collected from the surface (eight from greenhouses and two from vegetable gardens, $100 \mathrm{~g}$ each), 11 vegetables clumps (eight from the vegetable gardens and three from the restaurant), three samples of cat feces and a cadaver of kitten were collected.

The water samples were filtered using a filter membrane technique and processed as described by Franco et al. (2012). The sludge, in turn, was centrifuged in $50 \mathrm{~mL}$ Falcon tubes at 2,100 g/10 min, yielding a final supernatant volume of $50 \mathrm{~mL}$. The vegetables were processed according to Ferreira et al. (2018). The DNA extraction was performed using a commercial kit (NucleoSpin Tissue, Macherey-Nagel, Düren, Germany) according to the manufacturer's instructions, and DNA was eluted in a final volume of $50 \mu \mathrm{l}$. The PCR assays were performed as previously described by Homan et al. (2000) and amplified a 529 bp fragment.

A domestic feline, approximately six months old, was found dead during the investigation and referred for autopsy, sample collection (brain, heart, peritoneal exudate, liver, diaphragm and feces) were performed. The Sheater's technique (SHEATHER, 1923) was used to detect $T$. gondii oocysts both in the feces of the dead cat and the samples found in the environment. The other samples were divided into aliquots and stored under refrigeration until DNA extraction.

To identify the factors associated with the occurrence of the outbreak and the possible routes of transmission, such as food and water, a case-control study was conducted. Of a total of 26 individuals with symptomatology, 20 (77.0\%) subjects had compatible serological and symptomatic results with recent $T$. gondii infection and were included as cases. As controls, 45 asymptomatic employees who worked in the same staff and in the same work shifts were selected. The study ratio was 1:2.25.

Based on the initial date of the reported symptoms, the outbreak period was from December 10, 2015 to February 3, 2016, and the dates of the probable exposure were from $12 / 1 / 15$ to $01 / 21 / 16$, considering the mean incubation period of 20 days (EKMAN et al., 2012) of all the cases identified. The period with the highest concentration of symptomatic cases was between 01/10/16 and 01/16/16 (2nd epidemiological week of 2016). The general distribution of the symptomatic cases is shown in Figure 1 . The most frequently reported symptoms were nausea (100\%), headache (85\%) and lymphadenopathy (80\%) (Table 1).

Of the 20 patients, $55 \%(11 / 20)$ were males, with ages ranging from 25 to 60 years and a median age of 45 years. Regarding workplace locality, 20\% (4/20) of the cases came from Block 13 (the block in front of the restaurant), and 60.0\% (12/20) worked in manipulating land and planting. About the food consumption 


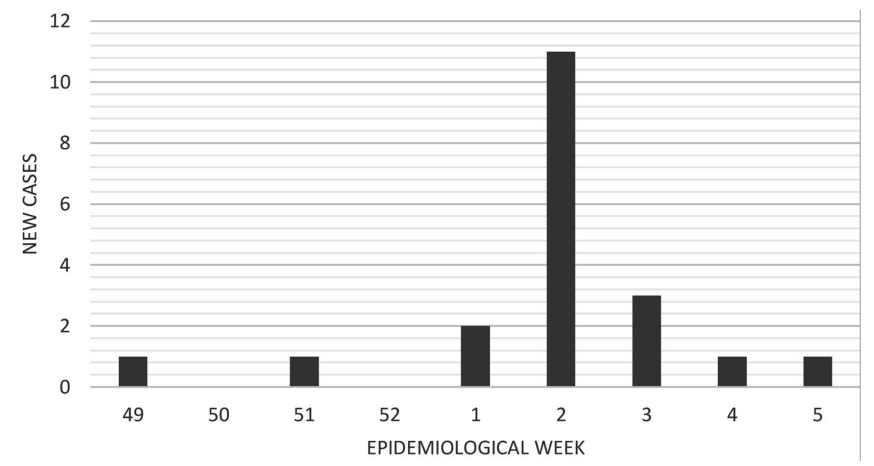

Figure 1. Number of cases per epidemiological week (onset of symptoms) in the outbreak of toxoplasmosis at a research institution in Londrina, Paraná, Brazil, 2016.

Table 1. Frequency of clinical signs manifested by cases during the outbreak of toxoplasmosis at a research institution in Londrina, Paraná, Brazil, 2016.

\begin{tabular}{lcc}
\hline \multicolumn{1}{c}{ SYMPTOMS } & (N/TOTAL) & FREQUENCY \\
\hline Nausea & $(20 / 20)$ & $100 \%$ \\
Headache & $(17 / 20)$ & $85 \%$ \\
Lymphadenopathy & $(16 / 20)$ & $80 \%$ \\
Myalgia & $(15 / 20)$ & $75 \%$ \\
Apathy & $(15 / 20)$ & $75 \%$ \\
Asthenia & $(9 / 20)$ & $45 \%$ \\
Cough & $(6 / 20)$ & $30 \%$ \\
Arthralgia & $(6 / 20)$ & $30 \%$ \\
Ophthalmic changes & $(3 / 20)$ & $15 \%$ \\
\hline
\end{tabular}

$\mathrm{N}$ - number

at the institution, all the patients drank water from drinking fountains and consumed vegetables, beef and chicken at the institution's restaurant.

Significant events were analyzed based on the habits, environment and food consumption in the institution, using the patients (20 individuals) and controls (45 individuals). The consumption of vegetables $(\mathrm{p}<0,05 ; \mathrm{OR}=14.72 ; 95 \% \mathrm{IC}=2.36-333.70)$ was the only variable significantly associated with the incidence of the disease, however the plant samples were negative in the PCR. It is known that even asymptomatic people can present serology compatible with acute disease (EKMAN et al., 2012), but in all cases commonly in outbreaks of toxoplasmosis, due to the amount of inoculum and strain, the presence of symptomatology is high frequency (DEMAR et al., 2007).

During the restaurant inspection, there were some irregularities noted, such as the presence of food without a record of origin and invoice, incorrect fractionation of portions with missing validity data, and presence dripping rain water under the grilled meats. In addition, the screens of two windows were destroyed, there were cats near the establishment, and inadequate washing of vegetables was observed.

The water samples, soil samples, vegetables clumps, cat feces and a cadaver of kitten were negatives in PCR.

Worldwide, outbreaks of toxoplasmosis are increasing in frequency, with water (BOWIE et al., 1997; MOURA et al., 2006), meat (EDUARDO et al., 2007), milk (SACKS et al., 1982) and vegetables (EKMAN et al., 2012; MORAIS et al., 2016) constituting transmission routes being vegetables in particular responsible for a growing number of outbreaks.

The workforce was approximately 800 people among servers, statutory and outsourced. The outbreak at the Londrina research institution affected 20 individuals. The relatively small number of cases $(20 / 800)$ reduces the chances that water served as the route of transmission for $T$. gondii. When contaminated with oocysts, water has a greater distribution, affecting large numbers of people and causing an increase in cases with time, as has been previously observed in other outbreaks such as those recorded in Santa Isabel do Ivaí, Brazil (MOURA et al., 2006) and British Columbia, Canada (BOWIE et al., 1997). In these outbreaks, unlike this case study, the appearance of the last case was less than 2 months after the notification of the first.

The number of cases reported in this study was superior to that of some outbreaks previously reported in Brazil (EDUARDO et al., 2007; EKMAN et al., 2012) and lower than that reported in the Santa Maria outbreak, Rio Grande do Sul, occurred in 2018 with a total of more than 800 cases being considered as the largest recorded outbreak in the world so far (data not yet published) and in Santa Isabel do Ivaí, Paraná, occurred between 2001 and 2002 with a total of 426 cases and is considered to be the largest recorded outbreak in the world so far (MOURA et al., 2006)

Like the other reported outbreaks (MASUR et al., 1978; MORAIS et al., 2016), the most frequent symptoms were nausea (100\%), headache (85\%), lymphadenopathy (80\%) and myalgia (75\%). Within the workplace, a greater frequency of patients was observed in Block 13. A likely explanation is that Block 13 is in front of the restaurant, and these employees were probably the first to have arrived and eaten from the same batch of food.

Due to inadequate hygienic conditions in the restaurant, it was not possible to reach the producers of the meat and vegetables. Traceability of these producers, even late screenings, would have been of great importance as they could have provided evidence of the primary sources of contamination and may have reduced the chances of new outbreaks (EDUARDO et al., 2007).

All the environmental and food samples yielded negative in PCR tests. However, these results did not rule out any of the possible transmission routes. The assessment of food and environmental samples in outbreaks of toxoplasmosis still presents a challenge, since the incubation period of the disease is long and consequently there are no stored leftovers, and water sources are renewed; these factors make it difficult to collect representative samples. There were few outbreaks where the responsible agent was successfully identified in samples, as was the case in the Santa Isabel do Ivaí outbreak (MOURA et al., 2006); identification was possible only since the school was closed and had stored water from the beginning of the outbreak period.

Based on the menus, incubation period, number of cases and epidemiological evidence, it is probable that the vegetables were the route of transmission of the outbreak. Fruits and vegetables have already been to be the suspected causes of various outbreaks of toxoplasmosis (EKMAN et al., 2012; MORAIS et al., 2016). In 2009, a similar outbreak occurred in a factory in São Paulo, with a total of 2,300 employees. These, 11 individuals presented with acute toxoplasmosis, a number that is lower than that reported 
in the present study; however, vegetable intake was also the main suspected cause (EKMAN et al., 2012).

The main points for contamination of plants by $T$. gondii and other parasites are during production. Horizontalization of agriculture makes it difficult to track microbes and assure food quality, since responsibility is decentralized and the goods are handled at a greater number of different establishments, increasing the chances of contamination during the entire process (washing, packaging, transport, storage, distribution and sale) (FERREIRA et al., 2018; PACHECO et al., 2003).

There was an outbreak of toxoplasmosis in Londrina, Paraná, involving 20 people. All possible routes of infection were investigated, but the agent could not be found. Epidemiologically, the likely route of transmission of the outbreak was raw vegetables consumed at the research institution's restaurant. The rapid recognition of the outbreak and notification could have broken the chain of the transmission early, preventing the appearance of new cases.

\section{References}

Brasil. Ministério da Saúde. Portaria n ${ }^{\circ} 4$ de 28 de setembro de 2017. Consolidação das normas sobre os sistemas e os subsistemas do Sistema Único de Saúde. Diário Oficial da República Federativa do Brasil, Brasília, set. 2017.

Bowie WR, King AS, Werker DH, Isaac-Renton JL, Bell A, Eng S, et al. Outbreak of toxoplasmosis associated with municipal drinking water. Lancet 1997; 350(9072): 173-177. http://dx.doi.org/10.1016/S01406736(96)11105-3. PMid:9250185.

Chiari CA, Neves DP. Toxoplasmose humana adquirida através da ingestão de leite de cabra. Mem Inst Oswaldo Cruz 1984; 79(3): 337-340. http:// dx.doi.org/10.1590/S0074-02761984000300007. PMid:6399092.

Demar M, Ajzenberg D, Maubon D, Djossou F, Panchoe D, Punwasi W, et al. Fatal outbreak of human Toxoplasmosis along the Maroni River: Epidemiological, clinical, and parasitological aspects. Clin Infect Dis 2007; 45(7): e88-e95. http://dx.doi.org/10.1086/521246. PMid:17806043.

Eduardo MBP, Katsuya EM, Ramos SRTS, Pavanello EI, Paiva OR, Brito $\mathrm{SN}$, et al. Investigaçáo do surto de toxoplasmose associado ao consumo de prato à base de carne crua ("steak tartar"), nos municípios de São Paulo e Guarujá, SP - Novembro de 2006. Bol Epidemiol Paulista 2007; 4(41): 1-6.

Ekman CCJ, Chiossi MFV, Meireles LR, Andrade Júnior HF, Figueiredo WM, Marciano MAM, et al. Case-control study of an outbreak of acute toxoplasmosis in an industrial plant in the state of São Paulo, Brazil. Rev Inst Med Trop São Paulo 2012; 54(5): 239-244. http://dx.doi.org/10.1590/ S0036-46652012000500001. PMid:22983285.

Ferreira FP, Caldart ET, Freire RL, Mitsuka-Breganó R, Freitas FM, Miura AC, et al. The effect of water source and soil supplementation on parasite contamination in organic vegetable gardens. Rev Bras Parasitol Vet 2018; 27(3): 327-337. http://dx.doi.org/10.1590/s1984-296120180050. PMid:30183998.
Franco RM, Branco N, Leal DAG. Parasitologia Ambiental: Métodos de concentração e detecção de Cryptosporidium spp. e Giardia spp. em amostras de água. Rev Patol Trop 2012; 41(2): 119-135. http://dx.doi. org/10.5216/rpt.v41i2.19320.

Homan WL, Vercammen M, De Braekeleer J, Verschueren H. Identification of a 200- to 300-fold repetitive 529 bp DNA fragment in Toxoplasma gondii, and its use for diagnostic and quantitative PCR. Int J Parasitol 2000; 30(1): 69-75. http://dx.doi.org/10.1016/S0020-7519(99)001708. PMid:10675747.

Jacobs L, Melton ML. Studies on the resistance of pseudocysts of Toxoplasma gondii. J Parasitol 1957; 43(5): 38.

Kolbekova P, Kourbatova E, Novotna M, Kodym P, Flegr J. New and old risk-factors for Toxoplasma gondii infection: prospective cross-sectional study among military personnel in the Czech Republic. Clin Microbiol Infect 2007; 13(10): 1012-1017. http://dx.doi.org/10.1111/j.14690691.2007.01771.x. PMid:17617185.

Masur H, Jones TC, Lempert JA, Cherubini TD. Outbreak of toxoplasmosis in a family and documentation of acquired retinochoroiditis. Am J Med 1978; 64(3): 396-402. http://dx.doi.org/10.1016/0002-9343(78)902188. PMid:637054.

Morais RAPB, Freire ABC, Barbosa DRL, Silva LCT, Pinheiro AF, Costa SS, et al. Surto de toxoplasmose aguda no Município de Ponta de Pedras, Arquipélago do Marajó, Estado do Pará, Brasil: características clínicas, laboratoriais e epidemiológicas. Rev Pan-Amaz Saude 2016; 7(esp): 143152. http://dx.doi.org/10.5123/S2176-62232016000500016.

Moura L, Bahia-Oliveira LMG, Wada MY, Jones JL, Tuboi SH, Carmo $\mathrm{EH}$, et al. Waterborne toxoplasmosis, Brazil, from field to gene. Emerg Infect Dis 2006; 12(2): 326-329. http://dx.doi.org/10.3201/eid1202.041115. PMid:16494765.

Pacheco MASR, Soto FRM, Fonseca YSK, Gomes AHS, Giancoli M, Leite Júnior AP, et al. Monitoramento das condiçōes higiênico-sanitárias de alfaces produzidas no município de Ibiúna, SP. REV NET DTA 2003; 3(2): 36 .

Petersen E, Borobio MV, Guy E, Liesenfeld O, Meroni V, Naessens A, et al. European multicenter study of the LIAISON automated diagnostic system for determination of Toxoplasma gondii-specific immunoglobulin $\mathrm{G}(\mathrm{IgG})$ and $\mathrm{IgM}$ and the IgG avidity index. J Clin Microbiol 2005; 43(4): 1570-1574. http://dx.doi.org/10.1128/JCM.43.4.1570-1574.2005. PMid:15814967.

Pomares C, Ajzenberg D, Bornard L, Bernardin G, Hasseine L, Darde M-L, et al. Toxoplasmosis and horse meat, France. Emerg Infect Dis 2011; 17(7): 1327-1328. http://dx.doi.org/10.3201/eid1707.101642. PMid:21762609.

Sacks JJ, Roberto RR, Brooks NF. Toxoplasmosis infection associated with raw goat's milk. JAMA 1982; 248(14): 1728-1732. http://dx.doi. org/10.1001/jama.1982.03330140038029. PMid:7120593.

Sheather AL. The Detection of Intestinal Protozoa and Mange Parasites by a Floatation Technique. J Pathol Ther 1923; 36: 266-275. http:// dx.doi.org/10.1016/S0368-1742(23)80052-2. 